\title{
Interview with Talal Asad
}

\section{Ovamir Anjum}

The work of Talal Asad, in particular his two landmark volumes Genealogies of Religion: Discipline and Reasons of Power in Christianity and Islam (1993) and Formations of the Secular: Christianity, Islam, Modernity (2004), has given new life to critical study of secularism and the idea of "religion" across the disciplines of anthropology, political science, religion, history, and colonial studies. In fact my first published article, "Islam as a Discursive Tradition" (2007), was a methodological inquiry into efforts to conceptualize Islam, focalized through the work of Asad and his interlocutors. The preface to my 2012 book on Islamic political thought remarked my broader indebtedness to Asad's notion of "discursive tradition" (against simple accounts of the "politicization" of modern Islam). Shortly after the book was published, in June 2012, I conducted a dialogue with Professor Asad in his Manhattan apartment, unique also for being a dialogue between an anthropologist and an intellectual historian. Our conversation spanned topics of mutual interest: secularism and the nation-state, democracy, Islamic tradition, the questions of reform and coercion, and too (what was at the time) Egypt's new revolution and so the possibilities and limits of Islamist politics. Since then, Asad has published articles which touch on themes we discussed (for example, the pair of 2015 essays in Critical Inquiry 41:2 and 42:1), and a few other interviews have appeared in which he also reflects on his intellectual trajectory and methodological considerations (see in particular the interviews by Fadi Bardawil and by Basit Kareem Iqbal). Now, nearly six years later after they took place, AJISS publishes an edited transcript of our 2012 conversations, both for their remarkable theoretical and biographical candor and for how, when read in relationship to the essays he has published since then, they make visible the development of a sustained argument regarding "tradition" and the project of modernity.

Ovamir Anjum is Imam Khattab Endowed Chair of Islamic Studies at the Department of Philosophy and Religious Studies, University of Toledo. He is the author of Politics, Law and Community in Islamic Thought: The Taymiyyan Moment (Cambridge University Press, 2012) and the editor of AJISS. 
To begin the dialogue, I invited Asad to reflect on three inter-related points. First, the near inseparability of politics and governance in Islamic history. Second, the specter of the modern death of the Sharia. Scholars like Wael Hallaq argue that the Sharia is today unfeasible (and thus that attempts by modern reformists are doomed) because many of the preconditions of the Sharia are today unavailable. Therefore, the possibility that Sharia is no longer a feasible tradition-in the way that philosopher Alasdair MacIntyre talks about the death or irrelevance of a tradition, when its essential commitment cannot survive a given rupture-is real. The issue of the death or fatigue of the Sharia is a critical question for my generation of scholars and historians of Islamic law. Indeed my book, Politics, Law, and Community in Islamic Thought: The Taymiyyan Moment (2012), and that of my friend Ahmad A. Ahmad, The Fatigue of the Sharia (2012), may be considered two responses to the gauntlet Hallaq has thrown. I wrote to Asad that his writings indicate both the continued viability of Islamic discursive tradition and too the specter of the "death of Sharia". Third, the inseparability of modern forms of democratic politics from market capitalism. Timur Kuran's Long Divergence: How Islamic Law Held Back the Middle East (2012) argues that the Middle East declined because the Sharia is distributive (as evidenced in its laws of inheritance, zakat, and prohibition of usury) and, crucially, has no concept of a corporation. Thus it prevented the massive accumulation of wealth, which is a necessary precondition of capitalism. Though I think Kuran is mistaken on many points in Islamic law and history, on the whole I agree with the thesis that Islam couldn't have produced modern capitalism. I asked Asad what prospects the Sharia has for providing an alternative. Should Muslims intellectually invest in Sharia as the point of departure for not merely a sustained protest against the powers of the modern state but for imagining a constructive alternative?

Asad's reflections on these three considerations then opened onto a broader conversation (conceptual, biographical, political), which is transcribed further below.

\section{$\$$}

Talal Asad: I haven't yet read Timur Kuran's work, although I have come across references to it. You agree with him on one major point: "Islam couldn't have produced modern capitalism." He regards this as an admission of Islam's failure and you don't. Of course I agree with you that the absence of "advanced capitalism" is not necessarily a failure. But you and 
Kuran are concerned with another question, as to whether Islam can produce capitalism. When I was a young man there was a debate in progressive circles around the question of why Islam failed to do so. Many of us assumed that history was-had to be-progressive and that societies could be seen as variously situated on the historical path marked out by the most "advanced" countries, some moving too slowly, others simply stalled. The failure of Islam to develop capitalism (and for socialists to prepare the future beyond capitalism) was regarded as proof of its political and moral inferiority. Many thinkers have learnt to problematize the assumption of progress as a self-evident good, although important global decision-makers still use the notions of "developing" and "developed" to classify and measure societies in their journey to reach "modernity." The abstract system we name "capitalism" (as part of a civilizational condition we call "modernity") was not something a particular historical agent aimed at and achieved. Many historians now recognize that the development of capitalism in the West was due not to "religion" or "religious law" but to a multiplicity of factors, some intentional and others contingent.

The fact remains that capitalist organizations now dominate the globe- "unevenly," as the expression has it-and they work, directly or indirectly, through the "sovereign" nation states into which the world is divided. People often refer to a feature of the modern world called "global governance": political, financial, and legal institutions that transcend nation states and profoundly affect the ways states are run and their inhabitants can live. The states themselves vary enormously in wealth and power, and their modernity consists primarily in their aspirations for economic development and political reform guided by liberal values. Given the variety of ethnic, religious, and linguistic forms of identity within these states, they are far less homogeneous than nationalist ideologists like to claim. This heterogeneity isn't simply an "internal" matter, for it also involves business, military, and emotional connections between parts of the population in one "sovereign" state and those in others, connections based on historical experience, traditions, interests, and the like. The solidarities and antipathies that are generated by these connections help to explain many of the features of the modern landscape: the feelings of solidarity between Muslims who live in different countries, the support given by Euro-American governments (and especially, but not only, by Jewish citizens in those countries) to Israel, antagonism to immigrants, Islamophobia, etc.

I have gone over these familiar points because in my opinion they are an essential context for thinking about "an Islamic alternative," and espe- 
cially about the role of the Sharia in such an alternative. That context doesn't dictate what the alternative must look like; it defines the constraints and opportunities to which one must attend. I would stress again that the modern state in which we all live is a dangerous body, necessary for achieving things we value as individuals and communities but capable at the same time of frustrating, limiting, and punishing us-especially for not being loyal. (Unlike earlier times, "loyalty" to the state is now rationalized as a condition of "security".) Beyond the state, but supporting and working through it, is the network of powers that maintains global governance-even more dangerous because it is less responsive to the demands of citizens than the "sovereign" state is. Islamists who believe that it is necessary to establish an Islamic state as a way of dealing with the destructive forces of global capitalism seem to me to grossly underestimate the repressive and destructive powers of the modern state-even if some states (North American and European states) are much more powerful in this regard than others. But the moral damage such a state can do, and not only to its non-Muslim citizens, should not be regarded as a trivial matter. That is why the state should not, in my view, be part of an Islamic political vision. Furthermore, Muslims in their own "Islamic state" cannot adequately confront the destructive forces of global neo-liberalism. This is not merely because the modern state is too weak in that context but also because it is too deeply imbricated in the workings of international capital; it is precisely for that reason that the latter gives crucial support to the repressive functions of the former. (This reminds me of an old argument among Marxists about "socialism in one country." To the extent that this doctrine was applied, the result was simply a more repressive nation state.)

Let me turn directly to the Sharia. Substantively, the Sharia is, as you know very well, no longer what it was some centuries ago. From a complex and flexible tradition that enabled the lives of many Muslims through the instantiation of a religious vision, it has been redefined and fixed as "law," and through that as the prime marker of social identity. Of course the Sharia can be "democratically" reformed as law, but its dependence on the modern capitalist state makes that less interesting because we already know what kind of law capitalism demands. I think one may be able to retrieve part of the moral dimension of the vision underlying the sharia if amr bi-l-ma' $\bar{u} f$ is re-conceptualized as a collective moral-political project-but only if it is entirely detached from institutions of the state, and if it abjures punishment. What, after all, does lā ikräha fi-l-dīn mean? (My father, incidentally, translates din as "moral law"; this is a little too Kantian, in my view, but it 
moves in the right direction.) Friendship, as you know very well, is a central value in Islamic tradition. Moral persuasion-i.e., persuasion that isn't a means of seducing someone into undertaking an immoral act-is the only right procedure in this matter, although persuasion may require more than purely verbal engagement. Thus if one thinks of civil disobedience as part of amr bi-l-ma'rüf it need not be seen merely as a negative action but as a mode of dissuading state power from undertaking (or continuing with) a vicious policy and thereby moving toward a moral vision that embraces all human beings (and all living beings). In my view this cannot be done-for moral as well as practical reasons-if one excludes "neighbors" who are not Muslims. Within the nation state as well as beyond it, links can be established with those individuals and movements that share at least some important objectives with Muslims who are prepared to engage in civil disobedience. How exactly such links are established will depend on the particular judgments of those who are politically active. Some acts of protest and demands will be framed by the existing limits of the nation state while others will call for linkages at an international level because most of the collective problems that confront citizens (poverty, environmental degradation, war and terrorism, etc.) cannot be addressed locally.

Nothing I have said seems to me to imply an abstention from democratic politics at the national level. On the contrary, they are part of the idea of a democratic politics that can draw on an Islamic tradition. Whether, and if so to what extent, party politics are essential to democracy is a difficult question. In any case I do not believe that Islamic parties should aim to capture state power because the result, unquestionably, will be that they will be captured by state power. Unlike several Muslim liberals, my argument about the state does not claim that secularism can be found in Islamic history. Secularity, in all its complexity, is modern; it involves a number of things (ontologies, sensibilities, assumptions about legitimate knowledge, and so forth) some of which are more closely connected together than are others. An Islamic politics proposing particular programs of reform would use moral suasion that depends on the force of argument (as in any sound public debate) as well as on the force of example. There is no reason why secular arguments should not be used-especially (but not only) when addressing non-Muslims. All I am saying is that it seems to me a mistake to think that Muslims have only one of two options: either to capture and use state power or to withdraw completely from "politics". Liberal democracy, and the party politics on which it rests, have irreparable flaws, but their principled abandonment may simply add to the repressiveness of the modern state. 
Ovamir Anjum: Turning specifically to contemporary Egypt: if my view of the Islamist dilemma is correct, then would a "weak government" - weak in the modern democratic sense of having no clear majority and divided politics-not entail weakness in negotiating against the neoliberal policies that the US and other global powers are clearly bent on imposing on Egypt? Would not an ideological opposition to global capitalism (and closely allied global militarism) be necessary?

TA: Understandably, one of the inevitable consequences of the 25 January uprising has been to focus the attention of Egyptians almost exclusively on Egypt, to reinforce the value and dangers of the state there. Ironically this is happening at precisely the time when people in the Arab and Muslim world are responding to events in Egypt with great interest and expressions of solidarity. One cannot say for sure what will happen there but I think that if the Ikhwan were intelligent and morally responsible they would try to make alliances with as many of the other parties as possible in order to defeat the army's candidate, Ahmad Shafiq, and prepare the ground for substantial reforms of public life. But these alliances will succeed only if they are based on genuine moves of inclusiveness - accompanied by legally binding concessions, not vague promises-on matters that will attract a range of social forces within Egypt (Christians, socialists, women, the poor, secularists, etc.) as well as potential supporters in the Arab world and beyond. This was what Abu al-Futtuh tried to do but the Ikhwan leadership turned against him. At any rate, simple ideological denunciations of global capitalism and militarism will not do-especially as many Ikhwan leaders are themselves highly successful businessmen, and their political shifts since the revolution have not been entirely re-assuring. Re-assurance will not come (and should not come) by way of declarations that they are determined to establish an "independent" Islamic state. In any case, I fear the opposition to the Ikhwan from the military, the business elite, the media, and the old Mubarak institutions is too strong.

You mentioned your book in your initial remarks. I think your attempt to retrieve a more community-oriented tradition within Islamic political thought was extremely interesting, as was the attempt to trace the relationship between faith and reason. I found what you had to say about Ibn Taymiyya much more enlightening than I had imagined I would. I had assumed that he was simply someone who was willing to take a harsh line on various political issues, which turns out to be a gross over-simplification. 
However, I think you need to discuss the question of rebellion. You do say something about it when talking about the spirit of the Sharia, I think where you talk about al-Ghazali. Ibn Taymiyya's position is to accept the ruler, however oppressive he might be, so long as he follows the Sharia. Does that mean he saw the Sharia as compatible with oppression? Yours is a historical work of course, but it would have been interesting to examine the issue of amr/nahy further, as I have been thinking about it myself. Amr/nahy could include a range of possible ways of opposing or resisting an unjust ruler. Not only are you supposed to stop someone who is acting immorally by word of mouth, or physically, you may also oppose him either individually or collectively. So I would include in the concept of $a m r$ and nahy the possibility not only of civil disobedience but also, in certain circumstances, of rebellion.

There is always the question, of course, of what one should do if non-violent civil disobedience fails. Are there situations in which forceful resistance becomes imperative, not just because it may be more effective but because it seems to be the only way of averting absolute disaster? I am not a total pacifist, but I would like to hear what contemporary answers from within the Islamic tradition have to say on this question. What do you think about Ibn Taymiyya's view that so long as the ruler follows the Sharia there is the obligation to follow him, thereby ruling out rebellion?

OA: Yes, I did discuss this briefly in my book. I also referred to Khaled Abou El Fadl's Law of Rebellion in Islam, which shows the complexity of this tradition in a more detailed way. I do show, for one, that the first century and half of Islam is (ironically) filled with rebellions that were supported and participated in by the greatest of Sunni authorities-in particular, the revolts of 'Abd al-Rahman b. al-Ashath in the Umayyad period and that of al-Nafs al-Zakiyya in the early Abbasid period. It is said that in one of them none of the hadith scholars or the jurists stayed behind. This is something with which I challenge my interlocutors who hold quietism to be the only Sunni position. They don't deny this history, but they interpret it through its historical consequences, in hindsight-that violence against the ruler is never good. There is this famous aphorism that "One day of anarchy is worse than sixty years of tyranny," as stated by Ghazali as well as Ibn Taymiyya. 
TA: Yes, and it has often been repeated by Orientalists to characterize Islamic political thought as essentially quietist. And yet one must bear in mind that social chaos is frightening for most people.

OA: The reason for this attitude, I think, was less theological or scriptural, but rather sublimation of certain historical lessons. Of course there were hadiths to this effect (prohibiting rebellion), but there are others, only slightly less explicit and forceful, that prompted in the direction you have mentioned, in which amr/nahy could take on the form of organized, armed rebellion, as indeed it did dozens of times in the first century and a half. But then one set of hadiths was privileged over others due to historical reasons. And Ibn Taymiyya was an exceptional historian.

TA: You don't talk about this enough in the book, do you?

OA: Right, I don't. I remember a fellow medievalist, Aaron Zysow, a remarkable scholar of Islamic texts, who teaches at Harvard and Princeton, saying in a lecture once, "Ibn Khaldun, he was an amateur compared to Ibn Taymiyya." It may sound shocking at first but it makes sense if one is speaking about intellectual history. On political history, of course, Ibn Khaldun was unparalleled. Ibn Taymiyya nonetheless surprises you with his insight and precise sense of historical development. In contrast, the mainstream jurists came to be quite weak in historical understanding. Al-Nawawi, for instance, complains of the jurists' weakness, and also says that the hadith scholars were usually better historians of their own tradition-hadith narrators, even though their interests were limited. Ibn Taymiyya was remarkable in that he seemed to know pretty much every intellectual trend throughout Islamic history. This is the knowledge that he used to mount his monumental challenge to all his contemporary scholarship. Nobody quite knew how to deal with him. He was not a typical scholar, who had become by then professors like us, known mainly for writing books.

Incidentally, another remarkable thing is that, unlike say al-Ghazali, Ibn Taymiyya doesn't betray doubt or inner struggle. As I argue in my book, some of this inner struggle for classical theologians was structural, due to a crisis in their attempts to harmonize reason and revelation. Islamic scholarship in the fifth/eleventh century was no longer as self-assured as it earlier had been.

TA: By that you mean not self-assured in a political sense? 
OA: I mean in their struggle against the Muslim philosophers. I argued that this was something the Kalam theologians constantly struggle with, for they ended up, in an attempt to reconcile reason and revelation, dividing the turf between the two, holding that reason trumps revelation before one comes to believe in revelation.

TA: That was a very nice discussion in your book, by the way, of Ibn Taymiyya's view that reason and revelation are mutually dependent and that this sets him apart from the argument of other thinkers over which of the two takes precedence.

OA: Right, that was a discovery for me too-that wasn't what I had expected to find. For Ibn Taymiyya, that dividing of turfs was incorrect in both cases, for revelation is self-reflective in that even prior to one's belief in it, it gives rational reasons for its own truthfulness, and in that once one has accepted revelation, one does not set aside reason, but continues to reason with the revelation. And this amounts to saying that Ibn Taymiyya was far more pro-reason in a sense than often understood.

TA: One of the things I was struck by on this particular point-and it'd be nice if you could say more in further publications, because you say it but don't quite bring it out-is that Ibn Taymiyya is discovering that there is no such thing as abstract "Reason" with a capital R. He is concerned with "reasoning", and therefore with the particularities of the situation in which one reasons and the things with which one reasons, the particularities of people's character, of their historical context, etc. The Enlightenment reinvention of "Reason" is a hypostatization, but Reason as a universal is not very helpful in understanding ordinary life. At times, I seem to think that that's what Ibn Taymiyya was saying. And that's why for him there was a mutual dependence between reasoning and engaging with revelation.

OA: Hallaq brings out some aspects of this in his Ibn Taymiyya Against Greek Logicians.

TA: Yes, Hallaq is a friend of mine-I read that book a very long time ago, I don't now remember it very well.

OA: But to go back to the point of rebellion, we have to remember that one of the ways in which the usual prohibition of rebellion against the ruler 
could be circumvented is that for the Hanbalis, takfir based on acts (rather than creed only) is easier to do-they could invoke "Whosoever does not rule by God's revelation is a disbeliever" and so rebellion could be justified.

Another reason is that for Ibn Taymiyya Sharia and justice, given his intervention in epistemology and ethics, are much more intermeshed and mutually implicated. For the formalist classical jurisprudence, one had to find a much closer relationship between an act and specific texts in order to establish its normativity, by which is meant ultimately its eschatological efficacy.

We have to remember that the state in the classical Islamic practice is always bordering on illegitimacy-the classical jurists did not wish to theorize politics in such a way to accord the existing military states legitimacy, but these states survived for about a millennium of course and quite frequently they did not uphold the norms and limits of jurisprudence in punishing certain types of crime-as Johansen notes, it was almost expected that the rulers would cross the boundaries of fiqh. This is the reason for Ibn Taymiyya's and his student Ibn al-Qayyim's frequent complaints against the formalism of classical jurisprudence. The norm was that the ruler would often violate the norms of fiqh, seeing the Sharia as too soft and impractical. For instance, I recount an incident in my book in which Nur al-Din, when preparing for jihad against the Crusaders, and committed to following the Sharia as articulated by the jurists in a way that was a somewhat rare display of submission by a sultan, receives a complaint from a governor that limiting court procedures to those approved by the Sharia has led to the rise of highway robbery because the two upright witnesses typically required to establish a crime by the mainstream jurists are rarely available in such crimes. Nur al-Din dismisses the request saying that the Sharia is perfect.

So, one way to look at this is that Ibn Taymiyya is interested in bringing together Sharia and the commonsense of ordinary Muslims and the logic of various Islamic projects. With the Sharia confined to a group of formalist jurists, it almost became a monopoly, and other erstwhile endeavors were left out of the reach of the normativity of the Sharia-for instance, the Sufis opposed their haqiqa to the Sharia of the "exoteric" scholars, the ulema; the rulers opposed their siyasa-real-life policymaking-to the theoretical and mostly ineffective jurisprudence, which they thought to be the Sharia, of the jurists; and similarly, the theologians created this dichotomy that we spoke of earlier. Ibn Taymiyya's grievance is that the Sharia cannot be limited to the direct implications of specific texts, by which the general command- 
ments of revelation, such as to uphold justice and benevolence and so on, lost any effect independent of the specific texts.

Another remarkable thing is the way Ibn Taymiyya conceptualizes power, as distributed in the society, rather than just limited to the rulers. So he frequently uses the phrase wulät al-umūr rather than khalifa, imām, or sulțān-in particular, in his al-Siyāsa al-Shar'iyya, al-Hisba, and other practical treatises - thus seeing the rulers as part of the continuum of power in the society. In the same vein, he speaks of amr/nahy as being general, a duty performed by all according their capacity and responsibility. This way of looking at power and authority was I think quite radical at the time, to the point that it did not really register in the politics and society of the time.

Baber Johansen, in his recent treatment, incidentally, completely ignores this aspect of Ibn Taymiyya, and says rather blandly that Ibn Taymiyya limits power to the rulers and the ulema.

TA: Could you send that reference to me? By the way, these are points you should develop in papers. I would urge you to do that. I think it is worth introducing your reading of the classical Islamic thinkers to your audience as quickly as possible to get some response.

OA: Yes, my painstakingly deliberative way of writing is a weakness. Sherman Jackson, a friend and mentor, also says the same to me. By the way, do you know him?

TA: No, unfortunately not. I have been hoping to meet him for some time, but last year when he came to a conference in the Graduate Center I was away in Cairo. I watched a lecture of his on YouTube once and liked it very much.

OA: $\mathrm{He}$ is a well-regarded American scholar of Maliki jurisprudence, among other things. Incidentally, he has a recent book on Islamic theology, which perhaps is the best introduction to the field. It is not opinionated, which is why it is quite unique in that it is even-handed toward the four main schools of Islamic theology—-the Traditionalists, the Mu'tazila, the Asharis, and the Maturidis.

TA: That would interest me, please do send me that reference too. 


\section{Biography}

TA: Are you originally from Pakistan?

OA: Yes, indeed. I was in fact thinking that my history is very similar to yours but flipped, in that I was born in Pakistan and grew up in the Gulf before coming to the US at eighteen. My ancestors came from Northern India where they had come, if one is to trust the tradition of family names, from Arab heritage. I started with Nuclear Physics, that was my first love. Then I switched over to the humanities and social sciences.

TA: Very good. I am glad you did.

OA: Then I went to Chicago to do an MA in social sciences, another MA in computer science, and then eventually came back to complete my $\mathrm{PhD}$ in history.

In other interviews you have talked about your childhood, but I am curious to learn a bit more. Let us begin with your early years in Pakistan. You have said elsewhere that you were not satisfied there as a young man, that you found rigidity of thought, and when you went to Europe, you expected something different.

TA: Right, I expected to find reason and tolerance there...

OA: And a lot of people do think that they find that in the West...so why did you see these issues so clearly? Was it the keenness of your observation or was it the times that made some of these things much clearer?

TA: I don't know. In fact, in some ways there is much greater hostility in the West today than there was at the time. There is no question about it.

OA: Perhaps precisely for that reason, one might feel betrayed when one's expectations are different.

TA: You may be right, but I don't know that I felt betrayed. I think in some ways it was being a person trying to think for myself, even to take a distance from my father to some extent. Now that I think about it... you are still young, you will see when you get much older that when one looks back over one's life one often sees things very differently, sometimes much more 
clearly. I remember being very deeply disturbed when I was about fifteen. This was in Lahore.

OA: You were in a boarding school then?

TA: No, I was not a boarder. The school was called St. Antony's High School in Lahore, run by the Order of Irish Brothers... Anyway, I wanted to say that I was deeply shaken in my faith when I was about fifteen, but I remember my father was very solicitous. I was surprised, because he could be very strict. He said I shouldn't be upset, that my doubt was a test of my faith and not anything abnormal. And I was surprised that in spite of that experience he eventually sent me to England to study architecture. I was eighteen. And I studied architecture for a couple of years before I turned to anthropology. Architecture was his choice, by the way-he said that it would give me the discipline I needed, and it would also give me scope for imagination, because, he said, I was an imagination chap. But in the end it didn't work, and I left architecture. I wanted to do anthropology instead.

OA: I want to talk about Pakistan a bit longer. Did you speak Urdu then?

TA: Yes I did! [In Urdu:] I have forgotten Urdu. I understand it. You too speak it, right?

OA: Yes.

TA: [In Urdu still:] I could speak Urdu once, but it was not spoken at my school. I studied it as a subject, as a second language.

OA: [In Urdu:] Do you ever go back to Pakistan now?

TA: [In English] Ah, I followed that! I went in 1983 or '84, to meet an oldtime friend of mine from high school, we were in the same class, Tariq Kamal Khan. He is now retired, he was the head of Pakistani Navy, an admiral-in-chief or something.

OA: Well, the military is a class of its own, different from the rest of us. 
TA: Well, yes, he is a Punjabi. I know that what the military, which is dominated by Punjabis, did in Bangladesh was absolutely terrible. But Tariq wasn't himself involved in that war of secession.

OA: That's not what I meant, but yes-one of the formative influences on me growing up was to be shaken by the burning of Karachi in the ' $80 \mathrm{~s}$, which began in the name of ethnic discrimination, and I saw the city go to flames. I have hated ethnic riots and demagoguery with a passion since. I was too young to evaluate what was being said in terms of discrimination. But to me, the Punjabi-Muhajir friction was a terrible tragedy. The city was never the same again. My own friends growing up in Jeddah were often Punjabi. In fact, my single best friend from school, the only one I have stayed in touch with, is Punjabi. (In our family in Karachi we have Punjabi and Pathan links by marriage, even though our ancestors migrated from northern India. This ethnic divide has been a terrible upset for us and for the city.)

TA: Tariq, who comes from Jhelum, from the landlord class, is one of my oldest friends-and yes, of course, the Punjab has been the dominant part of Pakistan. We had many friends that I remember. My father knew very well someone called Chaudhary Niyaz Ali Khan, who owned a very big fruit farm in East Punjab near Pathankot, part of which he made into a waqf, where, as it happened, Maududi and his followers settled.

OA: Did you ever meet Maududi?

TA: No, though my father did. I may have seen him with my father once but I am not sure.

OA: So, after eighteen, did you ever go back to Pakistan apart from this?

TA: Apart from the one occasion when I visited my friend Tariq, no, because my mother, allāh yarhamuhā, had left Pakistan. When my parents separated my mother, heart-broken, moved back to be with her family in Saudi Arabia, in Medina. So, there was no relative in Pakistan. I had a few friends but I didn't see them until I went back in the early '80s. I went to Islamabad, which didn't exist when I was a child. Then I went from Islamabad to Lahore in half an hour by plane, which was an extraordinary experience. I remember we used to go to Murray [in the hills beyond Islamabad] from 
Lahore by car, and it used to take a whole day. Lahore was totally changed when I visited it. It was a place I barely recognized. I remember an incident when I was being taken around to see the city: There used to be a large open space in front of a family friend's house where I lived while I attended school in Lahore. On this occasion I heard my young guides talking about how there used to be a cinema and beside it a restaurant there that had now been pulled down. I told them that I remembered a time before the cinema and restaurant were even built. It was a strange experience. We both saw and talked about the same empty space, yet the space I now saw seemed identical with the space in my memory, while their memory was of buildings that had been built and eventually pulled down-both after I left Pakistan; what they now saw was an empty space that had succeeded these vanished buildings. Their empty space and mine were ultimately quite different.

I had Saudi nationality when I first arrived in Britain, because at the time I left Pakistan there was no nationalization law in place that would have allowed me to become a naturalized Pakistani. The one that existed was inherited from British India, and it stipulated that the applicant (or his father or grandfather) must have been born in His Majesty's Dominions. But I needed a passport to travel to England, so my father went to his friend the Saudi ambassador who decided that since I was born in Medina I was eligible for a Saudi passport. Which meant that in London I had to register with the police every time I moved my lodgings, and this embarrassed some of my landladies.

When I switched my Saudi passport for a Pakistani one it made me a member of the Commonwealth, and that gave me the freedom to move and work as I pleased. I remember that I went into the passport office in London to surrender my Saudi passport and be removed from the status of "foreigner," and the British official smiled and said to me, "Welcome, now you are one of us!" That shows you how things have changed since.

OA: Interesting. I didn't realize that's what being a member of the Commonwealth meant. It seems now that it was always like this.

TA: No, not then. You were not a foreigner at all, you could come and go [in and out of Britain] freely. Then later they passed all sorts of laws that made it impossible to do so. But eventually, I think it was when I came back from the Sudan, that I decided to get British Nationality. This was just after the 
Bangladesh debacle. Since Pakistan walked out of the Commonwealth in '72 in protest at the recognition of Bangladesh, suddenly I was a foreigner again. The Home Office decided that Pakistanis would now have to register, but the police didn't like that because there were too many of us in Britain, so the government decide to give all Pakistanis British nationality.

OA: Did you speak Arabic then?

TA: Yes, I spoke Arabic to my mother, but you know, a child's Arabic.

OA: And till how late did you go visit her?

TA: I was with her for the last year of her life, which was 1978. She had advanced cancer, and my maternal cousin, 'Abd al-Aziz al-Dakhil, arranged for her treatment in Riyadh. I stayed with her that year, starting in early summer of 1977, and she died in the following summer, in 1978. I taught at Riyadh University until she died. But other than that, I had visited her every year in Medina, coming via Jeddah. She would always leave instructions in Jeddah for me to perform 'umra before I came to her, so I did, dutifully. So I have done about ten of them or so. (One of these days I would like to go for Hajj, in shä alläh, with some friends of mine.) So, anyway, I lived with her for a couple of weeks or so every year.

OA: So you haven't been there since the '70s? It has changed so drastically.

TA: Yes, I am told. I have only gone once very briefly as part of a team to write a report on sociology and social anthropology in Riyadh University.

OA: But you taught anthropology there in the '70s. And in Arabic?

TA: No, sociology, they didn't have anthropology. Teaching in Arabic was a bit of a strain for me at first. By the end I was reasonably fluent doing so.

OA: That is quite impressive. Speaking and reading Arabic is one thing, but teaching something like sociology, with all the terminological issues, that's quite something!

TA: Yes, of course, and I tried to lecture in a way they were not used to, critically, in which perhaps I was not very successful. I had studied Arabic 
in England for my A-level certificate, and then as an undergraduate at Edinburgh University, where Arabic was my second subject after Anthropology. And then, of course, I went to the Sudan in the '60s after doing my B.Litt at Oxford, and taught in Khartoum University (in English). After that I went repeatedly to Egypt. But Egyptian dialect is something I still find difficult. It often trips me up when they make qāf into a hamza and jim into gāf.

\section{OA: Do they figure out that you are a khaliji from your accent?}

TA: Yes, they do, and I tell them I get my accent from my mother.

OA: I remember when I'd go to Egypt, they can tell my accent is Saudi. If I told them that I was from Pakistan, they are much kinder, there is a much greater sense of fraternity. I love Egyptians, in particular the ordinary people, the sha'b. There is an incredible openness in that class of people. They are open to each other and to foreigners. The gender segregation is also much mitigated. There is this amazing communal spirit.

TA: Right. I love going to Egypt too, some of our closest friends are in Cairo. I often tell them that my heart is in Egypt but that my mind is in the West. It can be difficult, of course, physically and logistically, living there.

OA: Can we now talk about your father, and the specific critique of your father's position that you have? Did you ever confront him about the question of an Islamic state politics?

TA: No, not on this issue. Of course, one does not come to important positions just like that, one has to live through a variety of circumstances in which problems begin to emerge. He was quite keen on the idea of Pakistan as an Islamic state, as a unique experiment that was not based on race, ethnic origin, or other identities but simply on an ideological commitment to Islam. He kept this view all his life, I think. Although he later became less interested in the question of an Islamic state and more in the vision of the Qur'an, he never explicitly disavowed the former.

I was thinking about this when we were talking about Ibn Taymiyya, because I remember from childhood my father talking about him quite often. Having read your book, I can see many of the things that he would have found attractive about Ibn Taymiyya. I certainly never heard him say 
anything critical-in any case the reputation of Ibn Taymiyya as intolerant has emerged relatively recently with what is called "the rise of political Islam”. Ibn Hazm was my father's favorite, I think. So, no, I didn't confront him on the question of the state. In any case, his book Principles of State and Government in Islam didn't appear until the early '60s.

He could be very strict but he never once raised his hand against me, even when I was naughty. My mother did strike me when I was little, but he never did. I remember him quoting a hadith once, by the way, about how it was makrūh (disliked) to strike even an animal in the face. I was very impressed by that. My father was a genuine intellectual and he gave me considerable freedom of thought.

I have found that I underestimated what I got from my mother. She was barely literate-in her youth women in Saudi Arabia didn't go to school. But she read the Qur'an regularly, and one of my earliest memories as a boy is waking up from a nightmare in the early hours and hearing my mother read Qur'an, which was incredibly reassuring. But that's not why I said I obtained something valuable from her. I came to realize slowly that whereas my father was an intellectual (for him Islam was an intellectual system) for my mother Islam was just an embodied condition of being, and it was gradually over the years that I began thinking about her and her Islam. And so my intuitions about embodiment become more concretized and I realized that intellectuality was not the first and most important thing in thinking about "religion", that "religion" has no essential definition because it is coeval with life. In any case "religion" is not a good translation of din, that's why I often use inverted commas when speaking of "religion". My mother's Islam was a way of being, an attitude, a range of sensibilities, a physical condition-of course she said her prayers regularly and read the Qur'an and fasted, and all of that somehow permeated her ordinary life. I don't mean that she was "a good woman" but that her faith was not an abstract object. This contrast (between my father's intellectual and critical approach, and my mother's total absence of intellectuality) seems to me important in understanding "religion". This was how my mother lived and this was what she believed made her a Muslim. And I think, paradoxically, that's why she became important to me intellectually.

OA: Yes. That reminds me of how theologians like al-Ghazali and al-Juwayni would say toward the end of their lives that they wished for nothing but the "faith of the old women of Nishapur" ('ajā'iz naysābūr), leaving behind all of our delving into the oceans of theology and philosophy. At an- 
other occasion, in his I $h y \bar{a}$, al-Ghazali says that the faith of a theologian is like a thread hanging in the wind whereas that of a common believer is like an immovable rock. Very few people handle faith and reasoning together as lived experiences, these are not isolated instances. And what's interesting is that Ibn Taymiyya doesn't betray this doubt at all in any of his writings, which I find mysterious and incredible.

You seem to have been interested in Islamic tradition increasingly since the 1980s, when you wrote Genealogies. Was it the influence of your mother, or of her death?

TA: I think it may have been. When she died in 1978, I began to think about quite a number of things. Many of the papers that I wrote on the question of embodiment were written in the 1980s, although the book itself came out in '93.

OA: You mentioned that your faith was shaken around fifteen. How has your faith developed since? Is what we see in Genealogies a reflection of that development?

TA: Yes, I am increasingly struck by the need for getting into, thinking about, Islamic tradition and educating myself more in my old age about what it means, and trying to look at it as it were with fresh eyes. And that impetus is something that has become an important part of my life.

OA: When did your father pass away? And did that have an influence? How did he respond to your writings?

TA: He died in '92, and none of my books on religion had come out by then. I don't think he was terribly interested in my writings. There was nothing he could learn from them. He was very affectionate towards me, though. I remember him once saying to someone about me: "His imann is da'if" [his faith is weak] [laughter]. And I think that was not an unreasonable way of putting things. I have tensions in my thinking-sometimes I see things darkly, not only because of what the future may bring, but about the present and what it signifies and how it should be lived. I still have the habit of drawing on subversive genealogy, which is a kind of self-challenge. I am not comfortable with my writing. I don't like to read what I have published until 
long afterwards when it becomes "alienated", because I find myself doubting many things I've written.

OA: In fact I love that about your writing-how your self-reflection is evident there, already. I feel I am in sort of a jungle, not in a city with clearly marked streets, because it is not easily predictable where I am going and what to expect. And that makes me go back to them again and again, and challenges me to think.

TA: I try to explore things, you know. Somebody once asked me why I used the term "thinking" in many of my titles, and I said because thinking is a process that doesn't stop. I find it difficult to stop writing not because I want to perfect it-there is no perfection-but because I need to think through the act of writing. I explore things and find things I had not expected, some disturbing things and some that are pleasing. Exploration is what I want to do rather than apply a ready-made theory. I don't have a theory.

OA: What makes your style distinctive? Are there authors or genres of writing that have influenced you?

TA: For influences, I suppose, certainly some of the Western philosophers, because I know them better than I do Islamic philosophers. People like Collingwood and Wittgenstein, because they force me to think very closely.

\section{The Impossible State}

OA: Can we return to your critique of the idea of an Islamic state? You bring out the problematic nature of absolute loyalty to an Islamic state. But if we are talking about Islamists, I actually think that we do not have enough studies of what they were really trying to say. Take Maududi, for instance: he was a gifted thinker, a genius in fact, and a great writer. But I think he greatly suffered from the tendency and the need to present Islam in a final and unified voice, for a few reasons. South Asian Islam, for instance, had historically not seen the multiplicity of legal madhhabs that central Islamic lands like Egypt and Syria took for granted, and so just like Hanafism was the only real way to be Muslim, people tended to underestimate the possibility of various opinions that were equally legitimate or superior to theirs. In Pakistan, in particular, where Hanafism prevails so exclusively, the idea of codification of Islamic law, now seen as problematic by many, presented 
little difficulty_-for Hanafism had historically been attuned to being the law of the government, since Abbasid times. This, in part, was the result of the lack or loss of traditional learning in its fullness. Premodern Muslim scholars had this overwhelming sense of diversity within Islam-they speak as Hanafis or Sunnis or Ash'aris, but much less frequently simply as Muslims. Which has its own problems of course-sectarianism, parochialism, and lack of collective being and action, and so on. Twentieth-century Muslim activists, necessarily thinking in an anti-colonialist, collectivist mode, were both tired of sectarian rivalries-and we are not past the adverse effects of sectarianism - and also deprived of the opportunity to learn and appreciate the value of a diverse, rich tradition. So calls for loyalty to the state, including your father's ideas on the subject, which I think were a sophisticated version of the ideas that were quite common among the Islamists in his time, have to be understood in this context.

But there is another thing. To use Collingwood's question-and-answer metaphor, there is not enough appreciation in our studies today that the questions for Islam and Islamic actors throughout the twentieth century were so different. It seems to me that we haven't excavated those questions. So whereas I am very critical of the idea of the nation-state, even an Islamic one, deserving absolute loyalty, and one can be critical, as you are, on Qur'anic grounds, but also on Islamic-traditional grounds, one must further wonder, what is different in our view of the nation-state from that of the twentieth-century Islamists? Is our realization about the tyrannical powers of the nation-state, applicable as it is to the theory and practice of the developed states in the West, equally applicable to the much less developed, much less complete, much less stable, states in the Muslim world? Finally, Hallaq's claim that the Sharia is dead is based on the premise of near complete modernization of Muslim societies and state, which is not tenable.

TA: Yes, he says that in his book on Sunni legal theories. But his later books on Sharia and on modernity (due to appear shortly) are more interesting. I would urge you to read them. They pose questions about modernity that require a serious response.

OA: He overestimates, I think, the extent to which the modern state and law have replaced the Sharia in the Muslim world. One useful account which questions that premise is Anatol Lieven's Pakistan: A Hard Country, which argues how Pakistan's state and politics are not modern, that extend- 
ed family and tribal loyalties continue to play a significant role under the guise of democratic party politics. This incomplete modernization may be dismissed as corruption, and there is a great deal of that, but there is also something more-the possibility of not ending up in the same consumerist black hole in which modern capitalist democracies have ended up.

TA: I agree with you, but whether that means Pakistan doesn't have the aspiration to "complete" a modern state, that as a state it can escape the distorting effects of global capitalism and imperial subservience, is something I would dispute. Capitalism and politics are not the same in the Muslim world as in the West, of course. Things are quite different in different parts of the Muslim world too. And yet in most parts of the Muslim world (of what used to be called the Third World) there is the aspiration to "modernize" the state and the economy, to root individual and collective life in the state and the economy. Modernization, incidentally, is never complete-it is always part of an unending demand for forward movement. There was nothing like this in premodern times, even though some people held to an ideal model of the state. (It may be better to speak of governance rather than state in the premodern period, but it is unlikely that this will catch on.) Nevertheless, I think that something very radical has happened in Western Europe from early modern times with the gradual formation of what we recognize as the modern state (accompanying an increasingly dense global capitalism) whose most famous theorist is Hobbes.

What distinguishes this modern political formation is not only the claim to "sovereignty" within internationally recognized borders, nor simply the famous "separation of powers" (Legislature, Judiciary, Executive), but something that is presupposed by it: the state is constitutionally independent of both the rulers and the ruled, so that the political structure is something that has always to be worked through. It is true that it is individuals who are acting, but the very idea that there is a structure, a body, that they inhabit and that represents them, enables political actors to claim that their actions have a certain "legitimacy". When one speaks of legitimacy, one speaks of the political structure of the state and the law it maintains and dispenses.

I realize that the state as it is emerging everywhere is not the same. It is a trend and model. It is true that there are some conditions militating against it, it is true that there are attempts to subvert aspects of it, but everywhere the nation state that has emerged in tandem with global capitalism rests on a power that I think is terrifying. 
I think that we humans now find that this century may well be our last; if some of us survive it will be in a very different, a very unpleasant world. The dangers are so real, not only the vast unpredictabilities of climate change and the destruction of the environment and pollution of the seas, but also nuclear accidents (think of Fukushima), the militarization of space, the prospect of nuclear war. And the so-called "sovereign" state is central to all of this. Our modern civilization has presented us with an absolutely impossible predicament, one which may not be resolvable, I fear, because things are so interconnected.

Of course there are considerable differences among the states we find in the Muslim world-in Europe too, for that matter. But again, there is a tendency in virtually all modern states to take over greater and greater functions of control, to exert greater coercion and repression because of crises of the state and economy. Even the so-called liberal states are moving inexorably in that direction. And that movement is additionally justified by the global war against Islam, or terrorists, or by expectations of internal disorder. Of course one cannot tell with certainty what will happen. But things are pointing in the direction of continual economic, political, and social crises. All of this is contributing to the strengthening of state powers in a repressive direction.

And that is also happening in different ways and under different conditions in different Muslim countries, as I said. But that shouldn't rule out attempts to draw on various aspects of one's intellectual traditions to think of alternatives. I no longer think these will be adequate-not only because of the way global interconnections work, economically, politically, culturally, and ideologically, but also because the nature of the state in each one of these places has developed according to a not unfamiliar logic. Of course Egypt is not the US, Pakistan is not France, the US is not Britain. But there is a common political/economic language developing throughout the world that pushes people further into a morass.

Having said that, again, I see no reason why one shouldn't draw on the Sharia as a way of addressing questions of justice-whether, and if so, to what extent and in what way this can infuse the policies of a modern state is one question (about which I am very skeptical), but how it can contribute to the formations of moral disciplines independent-though not unmindful - of the state is quite another.

Which is why I was very intrigued by the notion of nași ha in Saudi Arabia and wrote a chapter on it in Genealogies, as you know. Nași ha can be addressed to people of authority, including rulers themselves, and in that 
way Islamic tradition is drawn upon. At any rate, my father was right-one must not start from the notion that the truth necessarily shines out from the West, that everything the West has produced is the standard for individual and collective life in the rest of the world.

I would like to see more studies of medieval Islamic governance. Is it necessary for the Sharia to be conceptualized as law? Since the nineteenth century the Sharia has increasingly come to be thought of as a series of laws, precisely because people are trying to modernize a state. One should carry out historical and anthropological studies in order to examine how (what we now call) morality, economy, religion, politics, and law worked in a society that wasn't "modern". Of course, some disagreements were justiciable, people had to resort to some institutions to resolve disputes, but these institutions were embedded in communities, they used different procedures, and operated on different assumptions about the nature of the human. I think we need more studies of that.

OA: Yes, we have far more attention given to aspects of legal history, but not enough looking at how these things worked together, which I take to be politics in its broader sense. My book is quite lonely in that regard.

TA: But it's an excellent book which should prompt others also to take on these questions.

OA: On the one hand you are quite pessimistic toward the modern state, but you also point to, here and in other writings, optimism that Islamists might be thinking of real alternatives...

TA: Or "hope", rather than optimism?

OA: Right, hope. But I notice that when you get down to it, you don't find what you were hoping for-that the Islamists in your view aren't really able yet to get past the desires and the conditions of legitimacy dictated by modernity. Myself I find sometimes that the more conservative Islamists might be more interesting, for they are not afraid to talk about the "ugly".

TA: But one has to think not only of political action, the distribution of power and the necessity of resistance, but also of institutions of teaching and learning, of inculcating Islamic values-which is neither the narrow-minded Wahhabi kind nor the disastrous modern kind. 


\section{On Freedom to Experience in Virtue Traditions and Liberalism}

OA: But to do that, to embrace a tradition of virtue and piety, involves refusing certain experiences and interactions. The tradition of Muslim piety, for instance, requires limiting what one sees and hears, and more. In contrast, liberal-capitalist ethics, if you will, requires of us to be open to all experiences and traditions.

TA: Well, that claim is not quite true. There are all sorts of limits that liberalism imposes and all sorts of exclusions it secures. Modern liberal society does claim to value multiplicity and variety of experiences, which seems attractive until you look carefully at what this means. Indeed, it justifies certain kinds of arrangement as being more open and tolerant when it isn't. The mere fact that there is supposed to be a multiplicity of views and preferences in modern society is given as the reason for the moral and political superiority of the market: because the market is the mediator among people who have very different preferences, it is the best possible arrangement for our egalitarian, plural world; that is what the market is-a way of responding equitably (neutrally) to the fact that people want different things, physical, intellectual, spiritual. So the market comes to be seen as the supreme value rather than merely a dispenser of multiple values. It creates a particular kind of society in which wants are generated and increasingly monetized, and so only certain kinds of social relations can flourish. The liberal-secular prescription is that one must accommodate every sort of experiences and belief, and one must value them all, but it ends up encouraging a specific kind of experience typified in the consumption of commodities. The market is not a neutral mediator of multiple values; it is an active constructor, a re-former of specific values.

To return more directly to your question: it is perfectly possible to want to limit one's experience in accordance with one's tradition. Thus the liberal attack on what some consider to be sacred, from the standpoint of their tradition, is dishonest because and to the extent that it discourages the shaping of experience beyond the market. But I am far less prescriptive, I think, than your question seems to suggest. I still have the habits of an anthropologist who is looking at a culture from outside. In this case I am looking at a culture in which I have spent most of my life, and which nonetheless seems to me to be deeply flawed, and I try to explore how and why that is the case. I see Western critiques of Islam from this perspective. I find a great deal of dishonesty in what is said there, a dishonesty that reveals something about 
modern cultural assumptions. But my explorations are not meant to be a refutation of these critiques; they are an attempt to interrogate the questionable assumptions on which they rest-so I question them.

Of course I am in favor of people following their own tradition with all that that implies, in terms of sensibilities, virtues, and cultivating humility in the face of the divine. But I think this is becoming more and more difficult.

OA: But it is often said that traditional societies are coercive and restrictive, whereas liberal ones, by definition, are not.

TA: Coercion is highly relevant to liberal societies as the inverse of "freedom". There is much talk nowadays, by intellectuals and politicians, about the importance of "freedom"; even our governments talk about defending it while at the same time using a variety of coercive measures, legal as well as illegal. Critics condemn these measures as "illiberal", but I'm not persuaded that a liberal democratic state can do without them in moments of crisis; the primary duty of the state is to defend itself, whatever it takes. Now that crisis is the permanent condition of our time (economic depression, extreme weather, political corruption, military quagmires, the threat of terrorism) piecemeal government coercion, and preparations for future repression of unruly populations, are increasingly difficult for liberals to oppose. Liberals claim that they are uniquely against human suffering, but I find that they are simply more comfortable with a "modern" geography of pain which they justify in instrumental terms.

But even in civil society coercion takes many forms. Take seduction, for instance. In many cultures to seduce someone sexually was a serious offense, subject to severe penalties. In modern society sexual seduction is not subjected to punishment. Sexuality has been largely "liberated" but the work of seduction remains largely overlooked. And yet seduction is basic to the way the market works (including the marketing of political personalities in national elections), but especially the marketing of things and the erotic imagery in which they are frequently purveyed. We don't think of sexual seduction as dangerous anymore, mainly because we regard every adult as possessing an autonomous will, as having the right to self-fulfillment (including sexual fulfillment), and as capable of being "persuaded". We think of persuasion as a good thing, as the working of reason itself-and aren't we all for reason? But there are many ways (rhetorical techniques) by which 
people are persuaded-seduced-into making immoral, cruel, decisions. That is where "free action" and "coercion" take place in liberal societies.

\section{On Opposing Genealogy to Tradition}

OA: In your interview with David Scott you express dissatisfaction with how MacIntyre opposes genealogy to tradition, in favor of the latter. But it seems to me that there is a fundamental difference between these two versions of moral inquiry - that an inquiry committed to genealogy with no acknowledged and consistently held frame of reference cannot be compatible with moral inquiry within a tradition, even if this inquiry is self-critical; that the similarity between traditional self-criticism and genealogical deconstruction in the tradition of Nietzsche and Foucault ends if one considers MacIntyre's main argument, which is crucially sensitive to fundamental premises of reasoning. It appears that you understand "genealogy" as a tool of inquiry whereas MacIntyre speaks of it as a metaphysical non-commitment to any truths, and taking that non-commitment itself as the point of departure for the inquiry of all else. What then do you make of MacIntyre's broader argument about the necessity of community and tradition for the development of rational-moral inquiry, as well as of virtue?

TA: For MacIntyre, Genealogy is necessarily subversive. But for him it is to be approved of when it is directed at Encyclopedia, because Genealogy undermines the latter's fundamental assumptions. But when MacIntyre juxtaposes Genealogy to Tradition he sees it as a moral failure.

I don't agree. I think MacIntyre is talking mainly about "discursive tradition" rather than tradition tout court. There is a tension between something that is lived, taken for granted, habituated, embodied, and something that is intellectualized in order to make it capable of being the object of critique. MacIntyre doesn't sufficiently distinguish between these two modes of Tradition. I think it is important to distinguish them, to examine the relationships between them, the way they intersect or stand apart, support or undermine each other, or remain indifferent to each other.

A discursive tradition needs to look back, as you show for Ibn Taymiyya, to look back and distinguish genealogically how things have come together to form what is true doctrine, what is reasonable and rational, why it has come to be taken for granted. When you take these things apart, you may be able to show that some aspects of a historical tradition were mistaken, some were not productive, and so on. In that sense, I see genealogy not 
necessarily as subversive of an entire intellectual tradition nor necessarily a threat to an embodied life of virtue.

In genealogy-and it doesn't have to be done exactly the way Foucault does it, and in any case there is a difference between his later work and his earlier work-the objective may be enlightenment of oneself, or it may be the reconstruction of one's tradition. It need not be an opponent whom one is unmasking, with resentment and animosity, as MacIntyre suggests. It may be a way of asking oneself or one's tradition whether what one has taken absolutely for granted is quite as unquestionable as it seems. One asks how and why it has come to be taken as self-evident. MacIntyre seems to accept genealogy as valuable so long as it adopts a critical posture toward the claims of encyclopedia, but he thinks that it is ultimately inadequate because it rejects the existence of an essence in tradition, because it disallows the possibility of an accountable (because continuous) self. MacIntyre's position in this matter, so it seems to me, leads to devaluing the potentialities of genealogy as a mode of intellectual inquiry (as a mode of doing intellectual history) rather than as an anti-morality.

In a related sense, people keep considering genealogy not as subversive but as a means of reforming Islamic tradition. I wonder if it is better to think not of reforming Islamic tradition but as living an Islamic tradition with the challenges which that offers. When there are challenges, dilemmas, questions, life will then require rethinking-sometimes more profoundly and at other times marginally. So the idea of reform strikes me-though everyone uses it, I have myself-as inadequate, especially when one thinks of what MacIntyre calls a vital, living tradition, because that by definition involves evaluation and requires appropriate responses to emergent difficulties. And this always brings up the question of what is essential to the tradition and what isn't. But this is not just an intellectual issue, not just a question of "reform". We need to think of what it means for people to live a tradition, not just what a living tradition is.

\section{On Accretist and Revivalist/Originalist Types of Traditionalism in Islamic History}

OA: Right, I too feel uneasy about the ambiguity of the concept of "reform". I wish to suggest, along the same lines, that what is intended by "reform" by those who take the tradition seriously might already be an inextricable part of Islamic tradition-thus I narrate the story of the Sunni tradition in terms of "accretists" and "revivalists". 
TA: By “accretist", I assume you mean what MacIntyre calls the Encyclopedist mode of inquiry?

OA: No, actually, I look at the contrast between two approaches to tradition in Sunni Islam, coming out of my work on Ibn Taymiyya. The first mode of receiving the tradition, if you will, builds on the immediate past, emphasizes continuity and embraces the developments, constructions, and syntheses added by each successive generation, thus upholding the growth and development of Islamic tradition by accretion. The most important manifestation of this synthetic posture has been the encounter of Islam with early Kalam, the Qadariyya and the Mu'tazila and then the Aristotelian and Neoplatonist falāsifa and so on. It distinguished itself by synthesizing and accepting elements of these traditions while defending to their satisfaction the orthodox doctrine of the salaf. They acquired their distinct identities, as Asharis or Maturidis, from this encounter. By the same process of synthesis, they incorporated Sufism into the mainstream. I call them accretist because they represented the tendency in Sunnism to synthesize and embrace constructions and foreign influence through intellectual synthesis, inevitably involving compromises, and this attitude is quite common. In the legal domain, for instance, they accept the growing authority of the madhhabs-which are a fourth/tenth-century historical construction, of course. But rather than theological or legal doctrines, I want to highlight the mode of dealing with change as being a better index of this tendency in Sunnism. Others, the strict followers of Ahmad b. Hanbal and the salaf, the original Sunnism if you will, rejected Kalam. They came to be known as the ahl al-athar or ahl al-hadith. They have been called "literalists" or "traditionalists" and so on, but these labels are inadequate. I have called them the "revivalist" tradition, because what sets them apart is their reception of any new developments with greater resistance, and their tendency to measure every change against the early Islamic model-and this juxtaposition is not necessarily literalist or rigid. For instance, the traditionalism of someone among the Hanbalis like Ibn Qudama and Ibn Rajab, or among the Shafi'is like al-Dhahabi and Ibn Kathir, that are strictly anti-Kalam and averse to rationalism, is different from the traditionalism of Ibn Taymiyya, Ibn al-Qayyim, or Ibn 'Aqil, who were trying to rationally reconcile tradition with revelation but in a way they believed to be more faithful to the salaf than the strand of Sunnism I have called accretism. I call them "revivalists"-with some unease. 
TA: Go back to where we started. How could one see both aspects of the followers of a tradition that you call accretists and revivalists as aspects of a continuing vital tradition? Because what you really want to say is that revivalism comes as a challenge to a declining or exhausted tradition that needs to be rejuvenated. I am still thinking myself about how to incorporate what one knows to be those waves of so-called "revival". I am not sure if you know Ahmad Dallal, who has been wanting for years to write a book about eighteenth-century revivalists. We know also that there have been these movements of revivalism from very early on.

OA: Right, I am familiar with Dallal's article on the subject. I do not mean by revivalism the well-known tradition concerning the coming of a revivalist at the turn of every century. But rather, what I meant was to label a way of receiving tradition in contrast with the natural accretion of tradition-the development that is inevitable in any tradition. In legal as well as theological domains one sees this construction and then a certain closing down of the doors of ijtihäd around the fourth century. So I use "revivalism" less in a moralist, traditionalist sense-and more as one of the modes of Islamic tradition, almost inherent to it, that wants to hold the received tradition against the standard of the early tradition.

TA: In that case I am not sure if revivalism is a good term. I wasn't entirely clear in what way you were approaching MacIntyre, either. At any rate, I think it might be worth your stressing that what he calls Encyclopedia should not be confused with what you mean by accretists, because there is a straightforward sense of progress that characterizes the nineteenth-century Encyclopedia tradition-while the modern notion of "progress" is not present among whom you call the accretists.

OA: Right, there is no sense of progress in the modern sense. Yet, there is some complexity. The accretist Sunni tradition differs from MacIntyre's Encyclopedists in the essential sense that knowledge for the latter is universal and based on self-evident, universal reason, whereas Islamic tradition, certainly the Sunni tradition, never puts reason on that kind of pedestal. On the issue of progress, certainly moral progress above and beyond the generation of the Prophet is unimaginable. Yet on intellectual progress, there is something. For instance, the Kalam theologians famously tried to justify their involvement in the kind of theology that the early Muslims clearly didn't by using arguments of necessity or of intellectual prowess of 
later Muslims. Al-Juwayni, for instance, said in his early writings that the salaf knew that there will come people who will understand the scriptural texts better than they; in his later writings, he rejects this notion. Even more clearly, Ghazali says in his Ihya $\vec{a}$ that had the Șahāba faced such intellectual opponents of faith as Islam faced in his time, they would have used Kalam. But in a later treatise, the very last one Ghazali wrote, he rejects this justification of Kalam, saying that the Sahāba indeed faced such opponents but still didn't use Kalam. There is an aphorism that sums up this attitude: the way of the salaf is safer (aslam), whereas the way of the khalaf is better-established or wiser $(a h k a m)$. So whereas there is no sense of linear progress in time, and certainly scholars like al-Juwayni even entertained the possibility of the "exhaustion of the Sharia" (futür al-sharì'a) due to the "absence of mujtahids", yet there is an almost sporadic sense of the khalaf having surpassed the salaf-but this sense is far from the modern idea of infinite progress, just that there is still room to think about and argue for rational development and improvement.

TA: It would be worth your writing a short article comparing Ibn Taymiyya and al-Ghazali in the way you have just done, without going into too much detail-I don't know of anyone who is doing this kind of thinking.

OA: Well, I'd say scholars are beginning to pay attention to Ibn Taymiyya and rethink, very slowly, the trajectory of Islamic thought with greater nuance. For instance, Professor Yahya Michot, who just moved to Hartford Seminary from Oxford, is a remarkable scholar working on Ibn Taymiyya. But a lot more needs to be done-and methodologically too, in recognizing the serious limits of and problems with Encyclopedia examining Tradition, as MacInyre would put it. Yet, seclusion or withdrawal from the secular university is hardly possible today, or even desirable, for all sorts of reasons. One must take Western knowledge as a point of departure, or at least the backdrop, for any serious rethinking of Islamic tradition, while recognizing that Islam has always been a networked tradition. Even in premodern times, when there was much less movement of ideas and people, Islamic tradition could not be localized for very long, there always came challenges from outside that local authorities had to account for and change in response to. One could only have transient formations that are governed or influenced by local conditions. So, rather than investing in something called "American Islam" (for example), one must take up Islamic tradition as it is, which is both an opportunity and a challenge for American Muslim intellectu- 
als. What I mean by this is that Muslim intellectuals from anywhere in the world, today as always, could criticize what I might have to say respecting Islamic tradition, and their location would not disadvantage their critique from a strictly traditional or moral or religious perspective, even if the academic demands on my work require paying far more attention to the kinds of critiques my American colleagues would offer. Only in the limited case of Islamic legal interpretation, which requires paying attention of local custom ('urf), would locality matter-and in a globalized world, even that is quite limited.

Part of what I am calling to do is not to limit ourselves to seminaries-granted their usefulness-but to nonetheless establish communities of Muslim academics writing as Muslim scholars committed to living and thinking Islamic tradition critically and in dialog with their disciplines. Though that may not go as far as MacIntyre's desired moral community, which he requires as the ground for the development of virtue. MacIntyre seems to value the idea of community as the necessary cradle of virtue, in contrast with the Kantian ethics of categorical imperative. And the significance, in the context of a community and its role-models, of the model you constantly aspire to and emulate but can never exceed.

TA: I think that such a community is far more difficult if not actually unsustainable in the modern world created by liberal capitalism. It must be in After Virtue that MacIntyre says that the era of barbarism is upon us and there is nothing to be done but withdraw into small communities, or something to that effect. This may just be possible. But I take it that you accept MacIntyre's idea of a community, up to a point, without thinking that that's the answer to everything?

\section{On Being a Muslim Academic}

OA: Indeed. More concretely, this means that Muslim academics working in secular universities should be willing to identify as Muslim scholars and contribute to the body of writings by Muslim public intellectuals who are proposing programs or particular reforms for Muslims, have conference and journals that take on the project of critically developing Islamic discursive tradition.

TA: I see that, and it is a good position to take. I would push you a little further, coming back to an enduring concern we've had. I think that it is 
not simply that Muslims have a moral obligation to engage continually in dialogue, but to use dialogue as a way of exploring new possibilities of the politics Muslims might pursue. What is taken for granted by so-called Islamists is the necessity for an Islamic state-and here, as I have said several times, I disagree. But I like the concept of "networks" as a way of exploring different kinds of politics.

But also kinds of democratic engagement, even to some extent through a party-system. As you know I am very skeptical of party politics, but that's the way politics is largely organized in the modern state. Party politics is at present indispensable and yet it is a treacherous mode of politics. There is a very tricky line here between taking for granted what exists and trying to mitigate the worst aspects of the modern state.

OA: Unfortunately, I have come to agree with your assessment in many respects, even though I think of myself as generally optimistic. We are already too late, it would seem, certainly with respect to developments such as climate change.

TA: What is further disconcerting is that even some of the principal artifacts of modernity that one has come to value turn out to be treacherous. Take democracy itself, for instance. I can't think of a better political system, and yet it is precisely because of democracy that we have a situation which can't be resolved. Can you imagine a government actually telling an electorate that has voted it into power that people must learn to want less, lower their standard of living, curb their desires for material goods? Such a government wouldn't last long. I'm not suggesting that a dictatorship is the answer-that would be much worse. I'm simply saying we are in an impossible situation and there seems no solution in sight.

OA: Muslim traditionalists have been talking about this for a long time, but only recently am I beginning to pay attention to them, to think beyond democracy: smaller communities, with some kind of shüra in place...

TA: But shüra is "consultation" rather than the right to elect and recall, and the authority to decide on the formation of policy. Is that what you mean?

OA: It could take a variety of forms, I think. But one thing that I find quite objectionable in modern democracy-that some modern Muslim intellectuals are buying into-is that states are now government solely by institu- 
tions and not individuals. Traditional Islamic political thought has always required that rulers are exemplars of rectitude and piety, cultivated in virtues, capable of ijtiha $\bar{d}$; their role is more moral and also more limited to the execution of the Sharia. The latter function in turn is divisible-thinking of the most developed form of Sunni political scholarship in the Mamluk period, in particular al-Qarafi and Ibn Taymiyya-into the siyāsa domain, based on generally agreed upon principles of Islam (and it is here that I see great room for democratic development), and the fiqh domain, where the juristic opinions, organized by traditional madhhab-communities, have reigned supreme. Governance-and I like your preference of this term over "state" to characterize premodern Islam-here was limited to defense, execution of law and maintaining internal order, and zakat and possibly tax collection and distribution, and some administration.

Now this was not a perfect model-society was too apolitical and consequently parochial, sectarian and unable to defend itself externally, unable to transfer power without violence and unable to hold the rulers sufficiently accountable. My book is precisely an attempt to point out these problems from within Islamic tradition. For some of these problems, some kind of democratic accountability looks extremely attractive, and that's partly why early modern Muslim reformers so warmly embraced the modern nation-state and the discourse on democracy.

So it is possible to think of alternatives to the current political institutions from within Islamic tradition. There are some transformations that would necessarily challenge the current form of the nation-state if the Sharia were taken more seriously: most directly, the transfer of authorities (of interpretation, dispute resolution, family law, and so on) from what the modern state claims for itself into the hands of socio-religious leaders, namely the ulema. The economic dimensions of the Sharia, such as prohibition of riba and division of inheritance, both interpreted away or ignored by many modernizers, are in fact quite crucial in restraining the ambitions of capitalism while also allowing a relatively free market economy. Similarly for the law of homicide (for instance), which was set aside by the colonizers for being too lenient and averse to bloodshed, in that in many cases it gives the family of the victim the option to forgive the killer-thus compromising the powers of the state. So I think that in a society that would take the Sharia more seriously, rather than disfiguring it into a tool for a modern state, authority and power would become far more layered and community far more empowered vis-à-vis the nation-state. 
TA: That's very interesting. I think you should continue to think along those lines. Also, I stress again that we are wrong in equating the Sharia with law. This equation is partly a retrospective categorization, the problematic use of a modern category to describe and use the Sharia. It is not enough to point to the gradual shrinking of the Sharia during the nineteenth century under colonialism. It seems to me that the Sharia also needs to be rethought in modern terms as something which isn't law-and I am not sure if we yet have adequate ways of thinking about it. The Sharia is not just "law plus morality" because our modern idea of law is itself one that allows for its connection with ethics. So besides the problem with the idea of the Sharia being straightforwardly law, there is the issue of what kind of category "law" was prior to the modern period and in non-Western societies. One needs to trace the genealogy of "law" as it gradually comes to take the form of a universal category integral to the modern state. It is a commonplace that after the dissolution of the Roman empire people in Western Europe as well as in the Islamic Middle East took over arrangements from "Roman law". But how did they understand and use what we now translate as law? How did it relate to what we would today call ethics? Anthropologists used to be very interested in such questions from a comparative cultural perspective, but not now. I think what we need is precisely enquiries into such questions. So that one aspect of rethinking the Sharia would require addressing these questions.

You asked me whether I see any difference in my work over the last couple of decades. For me what's always been important is to look critically at the Western heritage. I do think that if one looks at Islam as a networked tradition and not simply as localized (American Islam, French Islam, and so on), one will have to engage critically with other traditions, be ready when necessary to draw on them. Because to some extent they are also partly our traditions. As far as my intellectual heritage is concerned, I don't think of myself as having merely one (Islamic) tradition. There are several traditions of thought with which I am familiar, discursive traditions that are embedded in the institutions in which I live, and in the state and politics of which I am part, and so I look critically at them. Of course the Islamic tradition is one with which I centrally identify. But it is a mistake, in my view, to think of the Islamic tradition as the only one to which people like us (intellectuals living in non-Muslim societies) belong. These traditions are part of one's make-up, one's sensibilities, one's sentiments.

I referred earlier to the difference between an argued-over, discursive tradition and a tradition which may not be articulable-motives, practices 
and attitudes for which one may not be able to give reasons and may not need to do so. It's important to think of texts and discourse, of course. My simple point is that intellectual discourse is not the only important part of tradition, and that tradition in its entirety is not a coherent whole; its elements are interconnected, sometimes supportive, sometimes in tension with and sometimes contradictory to other elements-as human life itself is.

In Egypt up until the eighteenth century there used to a public practice during the Mawlid celebrations of reciting the whole of Șa hì $\bar{h}$ al-Bukhārī, and they would celebrate the khatm al-bukhärī at the end. This was not primarily an intellectual exercise but an expressive, reverential one. It led people to try and embody things that were reminiscent of the Prophet: because the Prophet liked perfume, they would perfume themselves, because he liked honey, they would eat honey, etc. All that was part of an emotional bonding with the founder of the tradition that one mustn't ignore-and it made up people's lives, how these were shaped, colored, infused. But one couldn't predict other aspects of people's lives from this desire to bond with the Prophet. So I would urge you to look at that entire domain in your recounting of Islamic traditions, as a space that is dynamically interconnected, as we proceed in our modern life with the dangers that threaten it and the promises it offers.

Interview conducted by Ovamir Anjum in June 2012 and edited by Basit Kareem Iqbal in January 2018 